\title{
Human Resource Management Practices Affecting Organizational Commitment: A Study on HR Managers Transformational Leadership in the Middle East
}

\author{
Nesiya Mattummathodi and Shanavas Moosafintavida*
}

Azteca University, Mexico, North America

*Corresponding author: shanavas.musafi@gmail.com

\begin{abstract}
This research aims to explore the moderating effect of HR Managers transformational leadership on the relationship between human resources management practice and employee organizational commitment. A total of 3,185 samples were surveyed of the top six out of 11 financial control groups in Middle East. Results indicate that, aside from performance management, the remainder of the variables, including education and training, salary and remuneration, benefits, career development, and communication, have significant positive effects on employee organizational commitment. A HR Manager transformational leadership, on the other hand, yielded no significant effect on employee organizational commitment. However, HR Manager's transformational leadership has significant positive moderating effect to the influence of performance management, salary and remuneration on employee organizational commitment, and significant negative moderating effect to the influence of communication on employee organizational commitment.
\end{abstract}

Keywords: Human resource management practices, HR Managers transformational leadership, organizational commitment, moderating effect

Human resource management practices affect an organization's performance. From the past empirical studies of strategic human resource management, we found that the firm-level human resource management practice is effective in improving organizational performance [5], [19], [20], [27], [42], [43], [63], [64], [26], furthermore, pinpointed the links between firm-level human resource management practices and corporate performance. He proposed that human resource management practices at the firm level affect employee's attitude, improve personal performance, and eventually enhance the company's overall performance. [5] human resource management practices were divided into two types: control and commitment. The control type, on the one hand, emphasizes efficiency, low labor cost, strict working 
rules, and result-oriented rewards, meaning regulating employee behaviors with rules and policies. The commitment sort of human resource management practices, on the opposite hand, reinforces modifying employee behaviors and attitudes through linking personal goals with the organizational goals. Under such system, employees are willing to trust the organization and thus, have high organizational commitment [9]. Therefore, this research aims to further explore the effect of human resource management practices on the worker organizational commitment. A company's management practice affects the employees' commitment to the organization.

The HR Manager's leadership stands as a part of this management practice. When a HR Manager has transformational leadership, he improves team competitiveness for the organization and is capable of conveying the organization's vision and goals to the employees and of making the workers identify themselves with the organization, get entangled within the organization's operations, and have high commitment to the organization. This inclination stands as the reason why many empirical studies have also found that transformational leadership style has significant positive effect on employee organizational commitment [28], [31], [35], [38], [39].

However, it is not necessarily true that firm-level human resource management practice yields an equivalent effect on all organizations. Empirical studies found that different organizational cultures [13], organizational climate [31], [38], [47], and organizational strategies [13], [19] [36], [40], [47], [65] have different effects on organizational performance. And at the individual level, [18] found that employees at different stages of career development have various cognitions and attitudes towards the different human resource management practices. Other factors, like employee comprehension of the organization's strategies, can also affect the organizational performance. A HR manager with strong transformational leadership style conveys the organization's goals and strategies to the employees [8]. Simultaneously, for the employees, since the human resource management practice is done based on organizational strategies, the practice would be closer to the organization's goals. This contributes to the development of organizational commitment. Therefore, if a HR manager has a strong transformational leadership style, he will be able to strengthen the effect of the human resource management practice (perceived by employees) on organizational commitment.

The three variables explored in this research, human resource management practice, HR Manager's transformational leadership style, and employee organizational commitment, are of three different levels: the firm level, group level, and individual level; therefore, they ought to be studied with cross-level analysis methods. However, changes of employee attitudes are reflected on the basis of their sensing of facts rather than facts themselves [54], therefore, the precise understanding of the effects of human resource management practices or HR Manager's leadership styles should be built upon the employees' cognitions. Furthermore, firm-level human resource management practice effectively upgrades employee cognition on the overall human resource management practices [14]. From this, we can see that implementation of the practice in an organization influences individuals' attitude through employee's cognition [16], [30], [23], [24] otherwise, change in the employees' attitudes is not likely to occur if the employees are unable to feel the benefits of the practices in their work or goals. For example, within the aspect of firm-level education and training systems, a number of these systems being considered more advanced could also be suitable to the workers consistent with the employees' positions and work styles.

Thus, even within the same organization, employees may have different cognition towards the same training. Their various attitudes or behaviors are consequently constructed. Many discussions regarding 
the effect of human resource management practices on employees' attitude also use individual-level cognition to represent the overall human resource management practices [11], [30], [18], [24], [25], [40], [48] [50]. Even when the HR manager treats different employees with the same behavior, the employees respond differently according to their personal considerations. Therefore, using employees' cognition to measure the HR manager's leadership style will be more obvious and direct than measuring it at the group level. This probability stands because the reason why during this research all three variables explored during this research are going to be measured at the individual level.

The "universalistic approach" is an orientation of the "best practice", considering that good or commitment sort of human resource management helps to realize high organizational performance. "Configurational approach" considers human resource management as a system and, to realize high organizational performance, all the practices must be "internal fit". And "contingent approach" considers that the workers maximize the organization's performance when those practices are fitted with the contingent factors (external fit).

\section{Objectives of Study}

1. The first objective of this research is to explore whether employees' cognitions of the individual human resource management practice affect employees' organizational commitment from the universalistic approach. From the test, we will also verify which practice has the foremost significant effect on organizational commitment.

2. The second objective of this research is to verify whether employees' cognitions on the HR Manager's transformational leadership reinforce organizational commitment.

3. The third objective of this research is to verify whether HR Managers' transformational leadership has moderating effects on the interaction between human resource management practices and the employees' organizational commitment.

\section{LITERATURE REVIEW AND HYPOTHESES DEVELOPMENT}

\section{Human resource management practices and employees' organizational commitment}

Employees' organizational commitment reveals the psychological link between them and their organization [12]. With a high level of commitment, they will have a robust belief within the organization's goals and values, wish to optimistically represent the organization, and eventually have intense desire to continue being members in it [46]. The concept of employees' organizational commitment in the past studies is a complex and diversified subject, but it is now considered as a multidimensional work attitude [2], [39]. Employee organizational commitment consists of three dimensions: affective commitment, continuance commitment, and normative commitment. Affective commitment refers to identification, involvement, and emotional link to the organization. Continuance commitment signifies the employees' cognition of the value involved in leaving the organization: they need to estimate the sacrifices when leaving the organization and remember of whether they could find another job. And normative commitment refers to the obligations to the organization as recognized by the workers. 
Organizational commitment is an important employee attitude. It affects personal job performance [33], [40], [39], [44], [34], [64], and consequently affects the organization's performance [10], [26], [27], [42]. However, the relationship between organizational commitment and performance is rather weak [15]. Some past researches using multidimensional approaches found that affective commitment has more notable relationship with performance [3], [28], [45], [58], [64], continuance commitment has no or negative relationship with performance [3], [45], [56], and normative commitment has no relationship with performance [28]. According to these studies, we can see that affective commitment is the most reliable for prediction of performance [36], [37].

The past empirical studies indicate that employees' organizational commitment and satisfaction are affected by the bundled policies in the human resource management practices [4], [19], [51],[64]. These policies include internal promotion, formal training system, and result oriented assessment. Employees' commitment and satisfaction are also influenced by employees' cognition towards these policies [16], [23], [40], [39], [64].

In the modern studies on strategic human resource management, human resource management practice is seen as a system; therefore, the effect of the entire system on organizational commitment is discussed nowadays, no matter the more conventional model of utility analysis. However, [34] the estimate of individual human resource management practice should not be abandoned. [57] also supports [34] by pointing out that the conventional utility analysis still has its practical values if it is properly adjusted. Thus, it is necessary to debate the effect of every individual human resource management practice. And the effect of every human resource management practice must undergo the method of employees' cognitions before it forms positive or negative attitudes of behaviors.

Human resource management practice also affects the results of human resource management (organizational commitment, quantity, flexibility) [26]. When a corporation has good performance management, employees are clear about their goals, the results, or feedbacks. When employees regard the performance assessment as fair, they need trust within the organization, willing to figure hard and consequently having high organizational commitment. Education and training help to enhance the employees' skills and abilities [26]. The more education and training employees receive, the more they think that the organization is willing to invest in employees. Therefore, the workers perceive that their organization sees them not because the tools for production but partners to get older together.

Employees identify themselves with the organization and thus have higher organizational commitment. Meanwhile, when the organization features a personalized reward system, its employees know that they're going to be rewarded if they exerting to realize the organizational goals, in order that they agree with the goals and have higher organizational commitment [26]; [40], [39]. An organization benefit system represents the organization's investment in the employees [61]. So, when the investment is enhanced, employees are willing to face by the organization, improving their organizational commitment. If the planning of the benefit system allows the workers to settle on freely, such participatory decision-making model helps the workers to regulate the progress of their work, so the employees have higher job satisfaction and therefore higher employee commitment [29], [30].

Employees identify themselves with the organization if they can see that their future career development inside of the organization if the organization is willing to develop the employees and facilitate for their growth. Especially, internal promotion directly affects the employees' motives or organizational commitment [26], [40], [39]. Otherwise, if the employees' opinions are always unaccepted or ignored 
or the organization has never communicated with the employees in terms of implementation of the company system, the employees would think that their organization doesn't value them. They will alienate themselves from the organization. Therefore, good communication brings organizational commitment. Implementation of the individual human resource management practice features a certain effect on the employees' organizational commitment.

Many past empirical studies have found that individual human resource management practice has direct correlation with employees' organizational commitment. In the area of performance management, the performance management system has significant effect on employees' organizational commitment [22]. The performance assessment has significantly positive and direct effect on employees' organizational commitment [50]. In the aspect of education and training, the relationship between employees' attitude towards training and employees' organizational commitment [7]. He found that the accessibility of cognitive training, social support on the training, motives, and therefore the benefits of cognitive training (job related) promote organizational commitment. In the area of salary and bonus, the bonuses have a significantly positive and direct effect on organizational commitment [50], and the performance bonuses significantly predict employees' organizational commitment [49]. In the area of benefits system, the satisfaction of the benefit system contributes to the prediction of employees' organizational commitment [60]. In the aspect of career development, the fairness in promotion could significantly reveal organizational commitment [49]. The internal labor market has significant and positive effect on the employees' organizational commitment [48].

The career development may significantly and positively present the direct effect of the employees' organizational commitment [50]. In the aspect of communication, the satisfaction with communication has significant connection with employees' organizational commitment [21], [53], [41] found that the level of satisfaction with communication relationship has strong correlation with the employees' organizational commitment. Based on the above studies, this research proposed the following hypothesis:

H1: Organizations that have better human resource management practices have higher employee organizational commitment

\section{Employees' organizational commitment and the interaction between human resource management practice and the HR Manager's transformational leadership}

The first to propose the concept of transformational leadership, believing that transformational leadership is a process. Leaders inspire their followers with a high ideology and moral values. Transformational leaders must be able to define and convey the organization's vision, while the follower must be able to accept the leader's creditability.

Some amendments to this concept of transformational leadership was made [7]. Generally, the concept of transformational leadership is divided into four dimensions: charisma or idealized influence, inspirational motivation, intellectual stimulation, and individualized consideration [33], [34], [35].

Leaders of the charisma or idealized influence style demonstrate the followers' admiration. Charismatic leaders exhibit trust and firm stance and attract followers emotionally. Leaders of the inspirational motivation style set out a vision to attract and inspire people. An inspiring leader sets the highest standards for the followers appropriately to achieve the goals and provide meaning to their hardworking. The followers thus feel the sense of achievement in a serial of challenges. Leaders of the intellectual stimulation 
style challenge assumptions, take risks, and inspire the followers. Such leaders stimulate creativity and encourage followers. A leader of the individualized consideration style listens to and takes care of each follower's personal need like a mentor or coach.

Because a transformational leader must convey the organization's vision to the followers, he/she makes the employees reach the identification with the organizational vision and then the organization itself, which will in turn result in input. And these results are manifestations of employees' organizational commitment. Empirical studies [28], [31], [35], [40], [39], indeed confirmed that transformational leadership style has a positive relation with the employees' organizational commitment.

From the foregoing, we can see that the source of organizational commitment is not limited to human resource management practices. The perception of transformational leadership can be regarded as the precursor of organizational commitment. Thus, if transformational leadership is absent in an organization, employees' organizational commitment will be reduced because the HR manager is not able to convey the organizational visions to the employees. The first two assumptions verified the main effects of organizational commitment. Because the organization's vision guides the strategies of the entire organization, and thus, guides the design of human resource management strategies as well as the practices themselves, when the leaders can clearly convey the vision of the entire organization to the employees, human resource management practices perceived by the employees is consistent within a HR Manager's leadership style. So, a HR Manager's transformational leadership behavior enhances the effect of human resource management practices on employees' organizational commitment. Better performance management in an organization makes employees know their job goals and expected feedback. A fair and objective assessment method helps to motivate employees; and once the employees maximize their potential, they tend to identify themselves with the organization and develop emotional dependence on the organization.

HR Manager's transformational leadership can be inspiring, of which the results of performance management enhance employees' organizational commitment. Education and training not only improve skills but also stimulate the potential of employees. When an education and training system is improved, the employees' skills are further complicated and made heterogeneous. Similarly, when the employees have better performance, they will be inclined to think that the organization sees the employees as assets, rather than liabilities; thus, the employees become more willing to stand by the organization.

If the HR manager can guide his or her subordinates to find their own answers to the problems in the workplace as a passage of intellectual stimulation, the employees' problem-solving skills will be reinforced and in turn they will have consensus with the organization at an even higher level. Therefore, this study expects that transformational leadership style can enhance the positive relationship between education and training organizational commitment. If an organization has an advanced reward system, such as the performance pay system, the employees know that they will be rewarded if they work hard to meet the organizational goals. If a HR Manager can influence the employees through an ideology, employees' identification with the organization will be strengthened.

A HR Manager's transformational leadership style will enhance the effect of the reward system on organizational commitment. When an organization has a comprehensive and flexible benefit system, employees are willing to stay in the organization because they think that the organization is willing to make consideration for their individual needs. They will consequently develop an emotional attachment 
to the organization. If a HR manager makes considerations to the employees' individual needs, the employees have more flexibility in their working.

Transformational leadership can enhance the effect of the benefit system on employee organizational commitment. If an organization has a transparent and objective system of career development, the employees are aware of their opportunities for development and will be more willing to stay within the organization. One of the transformational leadership dimensions, inspirational motivation, enhances the employees' willingness to remain in the organization, because, when the employees sense that they have opportunities for self-fulfillment and growth within the organization, they would be more willing to identify with and develop emotional attachment to the organization. Therefore, transformational leadership could improve the effect of career development on employee organizational commitment. When an organization has established more communication channels linking the management to the employees, information, including employee opinions and organizational goals, will be transferred faster. In such a case, the employees feel being valued and thus, reach the consensus with the organization.

A transformational leader can define and conveying organizational goals to the employees and such behavior is seen as an effective communication channel. When the leader in an organization can convey the organization's goals to the subordinates, a transformational leader should be able to reinforce the effect of communication on organizational commitment. Based on the above, this research proposes the following hypothesis:

H2: The HR Manager's transformational leadership has a positive moderating effect on the relationship between human resource management practices and employee organizational commitment. When the HR manager has high-level of transformational leadership, the human resource management practice have greater impact on organizational commitment; on the contrary, when the HR manager has lower level of transformational leadership, the human resource management practices have less impact on the employees' organizational commitment.

\section{METHODOLOGY}

\section{Data source and sample attributes}

The main data used in this study comes from the 2017 employee satisfaction survey of the top six financial holding companies in the Middel East (there are a total of 11 financial holding companies in the Middle East). The employees of the top six financial holding companies fill out the entire questionnaire. A total of 3,617 copies of the questionnaire were sent out and 3,185 valid copies of the questionnaire were retrieved. The return rate is $88.10 \%$. Data collection is conducted through onsite testing. The research assistant sent out and collected the questionnaire onsite. All questionnaires were completed anonymously. On the attributes of the samples, males take up 52.3\% and females 47.7\%. Age distribution: 26 to 30 years old, $25.3 \%$; 31 to 40 years old, $31.2 \%$; 21 to 25 years old, $16.9 \%$; over the age of $41.24 .3 \%$, and under the age of 20, 2.3\%. Years of service: less than one year, 15.1\%; over one year but less than two years, $18.2 \%$; over two years but less than three years, $22.7 \%$; over three years but less than five years, 26.4\%; and over five years, $17.6 \%$. Job categories: full-time employees take up $83.9 \%$ and part-time employees take up $16.1 \%$. 


\section{Variable measurement}

\section{Independent variables}

The measurement for human resource management practices was developed with references to [32] and [55]. Human resources management practices are classified into performance management, education and training, salary bonuses, benefit system, promotion and career development and communication system. Likert's five-point scale is used to survey the employees. Performance Management contains 9 questions, including "According to the company rules, the company's HR manager conducts two performance evaluations each year in January and before the end of July." Education and training contain five questions, including "The Company has a comprehensive education and training system". Salary and remuneration contain five questions, including "Compared with other financial companies, I am satisfied with my salary". The benefit system contains five questions, including "When working overtime as requested by the Company, the company pays overtime or gives me a compensatory leave day according to my choice". Career development has five questions, including "I am very clear about all the promotion and transfer opportunities in the company". Communication system has six questions, including "I believe the company's complaint handling system can really help me". From the effect of reliability analysis, we found that, excluding the benefit system, questions of other human resource management practices have internal consistency falling in between 0.82 and 0.91 , which are considered to have high reliability. Performance Management: $\alpha=0.8663$; education and training: $\alpha=0.8284$; salary and remuneration: $\alpha=0.910$; benefit system: $\alpha=0.8661$; career development: $\alpha=0.8742$; and communication system: $\alpha=0.8690$.

\section{Moderator variables}

The employees measure the transformational leadership based on the HR Manager's behavior. The scale is developed with reference to the transformational leadership dimensions used in Multifactor Leadership Questionnaire (MLQ) proposed by [6]. Six questions were developed. The five-point Likert scale was used to investigate the extent of agreement to each of the descriptions. Questions include "The Company's HR Manager gives the correct target and teaches me the necessary knowledge and skills needed for work and career development." The internal consistence of the questions is $\alpha=.9328$, which is considered to have high reliability

\section{Dependent variables}

Dependent variables are adjusted with reference to the questions survey on employee organizational commitment[1]. Five questions are used for measurement, including "I am willing to work hard for and grow with the company." Likert's five-point scale is used to investigate the extent of agreement for the descriptions of each question. The internal consistence of the questions is $\alpha=0.8758$, which is considered to have high reliability.

\section{Controlled variables}

From the pre-factor meta-analysis [44] in a survey on the subject of organizational commitment, we found that personal characteristics, that is, age, gender, years of service, and level of position, have significant 
effect on employee organizational commitment. somepast researches on organizational commitment demonstrated differences between full-time and part-time workers[59], but others found no differences between the two variables. Results of the meta-analysis are found to have differences. Therefore, this research classifies sex, age, years of service, and job type (full-time and part-time) as the controlled variables.

\section{Handling interactive variables}

To avoid occurrence of collinearity between the multiplication entries of interacting independent variables and the moderator variables, each interacting variable, including the six human resource management practices and HR Manager's transformational leadership, is standardized as a single variable before multiplying and, after multiplication, the variables are subjected to a regression analysis [17].

\section{Validity analysis}

There are eight variables in this study, including six human resource management practices, plus HR manager's transformational leadership and employee organizational commitment. To further understand the fitting between the factors and the questions in the measurement, this study uses Confirmatory Factor Analysis (CFA) to test the degree of fitting between the variables and measurement items. In this study, the eight-factor, three-factor, and one-factor models are used to compare the level of fit of the models:

Model 1 is a one-factor model and 46 items in the eight variables are treated as a single factor.

Model 2 is a three-factor model. Since human resource management practices have been considered as a system in human resources management related researches, this research sees six human resource management practices as a factor. Together with HR Manager's transformational leadership and employee organizational commitment, a total of three factors are subjected under a factor analysis.

Model 3 is the model we wish to validate in this research. Therefore, this research divides human resource management practices into six variables for study alongside the factors of HR Manager's transformational leadership and employee organizational commitment.

The results are shown in Table 1. The eight-factor model is the best factor structure model. Chi-square value divided by the degrees of freedom is less than 2 . In addition, the rest goodness-of-fit indexes are up to the best possible standard. The reason why the result of the chi-square value divided by the degrees of freedom is too small may be the effect that the number of samples is too large. Compared with other models, the eight-factor model is the best factor structure model.

\section{RESULTS}

\section{Descriptive statistics and correlation analysis}

Table 2 shows the descriptive statistics of all independent variables, moderator variables, the descriptive statistics of dependent variables, and the relations among the correlation coefficients of all variables. The correlation of the six human resource management practices and employee organizational commitment falls in between 0.50 and 0.70 , which indicates a significant positive correlation $(\mathrm{P}<0.001)$. The correlation 
of HR Manager's transformational leadership and employee organizational commitment comes to 0.557 , which also indicates asignificantly positive correlation $(\mathrm{P}<0.001)$. From which, we can see that all dependent variables have significant positive correlation with the moderator variables and independent variables. Thus, we will move to the next step - regression analysis.

Table 1: Results of goodness-of-fit from the confirmatory factor analysis

\begin{tabular}{llllllll}
\hline Model & $\boldsymbol{\chi}^{\mathbf{2}}(\mathbf{d f})$ & $\Delta \boldsymbol{\chi}^{\mathbf{2}}(\Delta \mathbf{d f})$ & $\boldsymbol{\chi}^{\mathbf{2}} / \mathbf{d f}$ & $\mathbf{C F I}$ & GFI & AGFI & RMSR \\
\hline One-factor & $243.56(968)$ & & 0.285 & 1.00 & 0.99 & 0.99 & 0.078 \\
Three-factor & $217.94(965)$ & $30.14(2)$ & 0.251 & 1.00 & 0.99 & 0.99 & 0.071 \\
Eight-factor & $149.78(937)$ & $89.91(26)$ & 0.168 & 1.00 & 1.00 & 1.00 & 0.053 \\
\hline
\end{tabular}

Note: $\mathrm{N}=3183 ; \Delta \chi^{2}$ and $\Delta \mathrm{df}$ represent the variances of $\chi^{2}$ and degree of freedom $(\mathrm{df})$ between models. CFI=Comparative Fit Index; GFI=goodness of fit index; AGFI=adjusted goodness of fit index; RMSR=root mean square residual.

Table 2: Descriptive statistics and correlation coefficient of the independent variables, moderator variables, and dependent variables

\begin{tabular}{|c|c|c|c|c|c|c|c|c|c|c|}
\hline Variables & A. $\mathrm{V}$ & S. D & 1 & 2 & 3 & 4 & 5 & 6 & 7 & 8 \\
\hline Performance Management & 3.92 & 0.621 & 0.8252 & & & & & & & \\
\hline Education and Training & 3.88 & 0.651 & $0.502 *$ & 0.8149 & & & & & & \\
\hline Salary and Bonus & 3.37 & 0.723 & $0.523 *$ & $0.519^{*}$ & 0.8813 & & & & & \\
\hline Benefits & 3.72 & 0.592 & $0.512 *$ & $0.542 *$ & $0.531 *$ & 0.8721 & & & & \\
\hline Career Development & 3.70 & 0.626 & $0.573^{*}$ & $0.572 *$ & $0.597 *$ & $0.613 *$ & 0.8537 & & & \\
\hline Communication & 3.61 & 0.672 & $0.629 *$ & $0.562 *$ & $0.672 *$ & $0.635^{*}$ & $0.629 *$ & 0.8473 & & \\
\hline HR Manager's T. Leadership & 3.85 & 0.692 & $0.647 *$ & $0.506^{*}$ & $0.512 *$ & $0.523 *$ & $0.541^{*}$ & $0.519^{*}$ & 0.9186 & \\
\hline Employee Org. commitment & 3.84 & 0.638 & $0.611 *$ & $0.597 *$ & $0.578^{*}$ & $0.602 *$ & $0.698^{*}$ & $0.675^{*}$ & $0.557 *$ & 0.8675 \\
\hline
\end{tabular}

Note: $* \mathrm{P}<0.001$. The $\alpha$ value inside of the () at the diagonal position is the value of internal consistency analysis. Sample number falls in between 3122 and 3183. (A.V: Average Value and S.D: Standard Deviation).

\section{The effect of human resource management practices and HR Manager's transformational leadership on employees' organizational commitment}

The hypotheses of this study are mainly verified by the hierarchical multiple regression analysis. From Table 3, we can see that Model 1 is a regression analysis with input of the controlled variables. Model 1 shows significant effect. $\mathrm{F}=14.336$ and $\mathrm{P}<0.001$, which indicates that Model I reach the significant level. In addition to gender, the controlled variables, including age and job type, yielded significant positive results $(\mathrm{P}<0.01)$.

Years of service, on the other hand, has a significant negative effect; $\mathrm{P}<0.01$. Model 2 is added with seven independent variables, including performance management, education and training, salary and bonus, benefits, career development, communication, and HR manager's Transformational Leadership, as well as the moderator variables, to test the main effect. From the regression analysis, we found that $F$ value of model 2 is 179.666, which reached the significant level $(\mathrm{P}<0.001)$, and $\Delta \mathrm{R} 2$ also reached the significant level $(\mathrm{P}<0.001)$. 
Through the regression coefficients of each individual independent variable and the moderator variables, we found that no significant effect is shown in performance management and the HR Manager's transformational leadership, but five of the perceptions on human resource management practices, including education and training, salary and bonus, benefits, career development, communication, etc., have a significant positive effect; $\mathrm{P}<0.001$. Therefore, most of the hypotheses proposed by this research are supported by the results.

\section{The moderator effect HR Manager's transformational leadership}

In Table 3, Model 3 shows the results of validation on Hypothesis II. Model 3 has an F value $=148.733$, which reached the significant level $(\mathrm{P}<0.005)$ and $\Delta \mathrm{R} 2$ also reached the significant level $(\mathrm{p}<0.005)$. After testing the regression coefficient of the cross-multiply items of the individual human resource management practices and the HR Manager's transformational leadership, we found that the cross-multiply items of performance management and HR Manager's transformational leadership yielded a positive significant effect ( $\mathrm{p}<0.05)$, but the cross-multiply items of communication and the HR Manager's transformational leadership has a significant negative effect $(\mathrm{P}<0.01)$, and part of the cross-multiply items of salary and bonus, as well as benefits, have a significant positive correlation with HR manager's transformational Leadership $(\mathrm{P}<0.10)$.

Education and training and career development, on the other hand, do not have significant correlation with the cross-multiply items of HR Manager's transformational leadership. So, HR Manager's transformational leadership regulate the effect of human resource management practices on employee organizational commitment in positive terms, as proposed in Hypothesis II, which also means that Hypothesis II is partly supported by the results.

Table 3

\begin{tabular}{llll}
\hline Variables & Model 1 $\beta$ & Model 2 $\beta$ & Model 3 $\beta$ \\
\hline Controlled Variables & & & \\
\hline Gender & -0.015 & 0.042 & $0.042+$ \\
Age & $0.179^{* * *}$ & $0.086^{* * *}$ & $0.084^{* * *}$ \\
Years of Service & $-0.093^{* *}$ & -0.017 & -0.008 \\
Job Type & $0.145^{* * *}$ & 0.017 & 0.017 \\
\hline Independent variables & & & \\
\hline Performance Management & - & 0.042 & 0.049 \\
Education and Training & - & $0.261^{* * *}$ & $0.262^{* * *}$ \\
Salary and Bonus & - & $0.126^{* * *}$ & $0.126^{* * *}$ \\
Benefits & - & $0.157^{* * *}$ & $0.158^{* * *}$ \\
Career Development & - & $0.182^{* * *}$ & $0.183^{* * *}$ \\
Communication & - & $0.286^{* * *}$ & $0.276^{* * *}$ \\
\hline Moderator variables & & & \\
\hline HR-M's transformational leadership & - & 0.026 & 0.026 \\
\hline Interactive items & & & \\
\hline Performance management x HR Manager's transformational & - & - & $0.078^{*}$ \\
leadership & &
\end{tabular}




\begin{tabular}{|c|c|c|c|}
\hline $\begin{array}{l}\text { Education and training } \times \text { HR Manager's transformational } \\
\text { leadership }\end{array}$ & - & - & -0.024 \\
\hline Salary and bonus $\times$ HR Manager's transformational leadership & - & - & $0.065+$ \\
\hline Benefits $\times$ HR Manager's transformational leadership & - & - & $0.053+$ \\
\hline Career development HR Manager's transformational leadership & - & - & -0.051 \\
\hline Communication $\times$ HR Manager's transformational leadership & - & - & $-0.096 * *$ \\
\hline R2 & 0.053 & 0.701 & 0.728 \\
\hline$\Delta \mathrm{R} 2$ & $0.503 * * *$ & $0.612 * * *$ & $0.008^{*}$ \\
\hline $\mathrm{F}$ & $14.336 * * *$ & $179.666 * * *$ & $148.733 * * *$ \\
\hline
\end{tabular}

Note: $\beta$ value is a standard regression analysis coefficient. $* * * \mathrm{P}<0.01 ; * * \mathrm{P}<0.01 ; * \mathrm{P}<0.05 ;+\mathrm{P}<0.10$.

\section{DISCUSSION AND CONCLUSION}

Researches on human resources management practices in the past are focused on one single practice or study on the effect of some practices on employee attitude or performance. However, when more and more studies confirm the relationship of cause and effect, discussions on the intermediary factors and moderator factors will be a refined discussion on the formation of the cause-and-effect relationship and facilitate in-depth understanding of the relationships among the phenomena. From past empirical studies, we found that human resource management practices affect the attitude of the employees, particularly organizational commitment. This study added the factor of HR Manager's transformational leadership to explore the effect of human resource management practices on employee organizational commitment. We use the HR Manager's transformational leadership as the contingency factor to explore whether there are differences in the degree of effect among the various human resources management practices as on the variable of employee organizational commitment within the context of the HR Manager's transformational leadership.

From the foregoing analysis, we can see that, in Hypothesis I, in addition to performance management, the other five human resource management practices are supported. Human resource management practices have significant positive effect on employee organizational commitment. As for Hypothesis II, on the one hand, the interactive effect of performance management and the transformational leadership has a significant positive effect on employee organizational commitment. The interactive effect of communication and the HR Manager's transformational leadership, on the other hand, shows a significant negative effect. The interactive effect of salary and bonus, benefits and the HR Manager's transformational leadership, shows significant positive effect partly, and the interactive effect of education and training, career development, and the HR Manager's transformational leadership does not have significant effect on employee organizational commitment. Therefore, Hypothesis II is partly supported.

Results of this empirical study show that education and training, salary and bonus, benefits, career development, and communication have significant positive effect on employee organizational commitment. This finding is consistent with those of [21], [48], [50], [53], and [49]. In addition to performance management, the individual human resources management practice affects the employee's attitude. The Study pointed out that the relationship between performance management and employee organizational commitment [22]. They found that, in fact, not all performance management practices have correlations to employee organizational commitment. They found, in their research, the difficulties in achieving the 
performance goals, which stressed that none of the factors, including peer competition, emphasis on short-term goals, the link between effort and performance, and the understanding in development, shows significant effect. This study measures performance management practice as a variable; therefore, some measurement questions (that is, the Company's HR Manager's provides guidance on how to improve my job performance during performance evaluation) is consistent to the concept. This caused weakening in the effect of performance management on employee organizational commitment and insignificant effect was shown.

Other human resource management practices have positive effect on organizational commitment. When an organization's training system is more complete, the more it will allow the employees to learn the skills needed and use the skills in their work, as well as develop the ability to solve problems, because the training system enables the employees to grow and have more control of their work and reduce frustration. The employees therefore become more willing to remain in the organization and develop emotional attachment. If an organization can provide better salary and bonus, this means that the organization can provide better economic rewards to the employees, so the employees are more willing to stay in the organization. If an organization can provide flexibility in the benefit policy, the employees would feel that they have more autonomy and are more respected, so they are more willing to identify with the organization. When an organization provides fair opportunities and a transparent promotion system, the employees' development can be anticipated and thus they become more willing to identify with the organization. Effective, moderate, and warm communication allows the employees to fully express their views and receive satisfactory responses, which yields the same effect as training. Employees feel respected, so they are more willing to commit to the organization.

The first contribution of this study is that it once again verified the effect of human resources management practices on employee organizational commitment. In the context of management, if an organization has good human resource management practices and the employees are aware of the practices, better employee attitude will be developed. Thus, if an organization wishes to have employees with a positive attitude, it can be achieved by providing commitment type human resources management practices; especially, a comprehensive system of education and training, satisfactory salary and bonus, flexible benefits, open and fair career development opportunities and, effective, moderate, and warm communication are effective in the improvement employee attitude.

And in the relationship of the moderator variables of the effect of the HR Manager's transformational leadership, as an individual human resource management practice, on employee organizational commitment, we found that the interactive items of performance management and the HR Manager's transformational leadership have positive and highly significant effect, and the interactive items of salary and bonus, as well as benefits, and HR Manager's transformational leadership have a positive and moderately significant effect. The interactive items of communication and the HR Manager's transformational leadership have a negative and highly significant effect, and no significant correlation is found in the interactive items of education and training, as well as career development, and HR Manager's transformational leadership.

HR Manager's transformational leadership is positively moderating to the performance management, salary and bonus, and benefits on employee organizational commitment. When HR Manager and his/ her employees work together to make the performance goal, the former is responsible for performance evaluations. Salary and bonus and benefits, that is, flexible welfare, are similarly HR Manager's responsibility. Therefore, when HR Manager's transformational leadership is higher, it helps to enhance the 
effect of human resource management practices on employee organizational commitment. The moderating effect of HR Manager's transformational leadership, education and training, and career development on employee organizational commitment was not significant. The main reason should be that these systems are usually set openly by the organization, so even if the HR Manager has high transformational leadership style, it would still be out of his power to enhance the more personal factors of the employees, such as education and training and career development.

The greatest contribution of this study is that it achieved further understanding in the moderating effect of HR Manager's transformational leadership, as a human resource management practice, on employee organizational commitment. The results of this study offer the organizations the insight that a HR Manager's transformational leadership must be fully manifested, and these leadership behaviors include guidance and employee training, conveyance of the organization's strategic goals and vision at the key meetings, and linking employees' work goals the organization's goals. A HR Manager demonstrates transformational leadership behaviors and the interaction between communication and a HR Manager's transformational leadership appears to flow in a negative direction. This also represents that communication and the HR Manager's transformational leadership are mutually replaceable. HR manager leadership is also a kind of communication channel, so when an organization is unable to design an effective communication system; a HR Manager's transformational leadership behaviors can be used to replace the formal channels of communication for proper conveyance of the organization's goal and vision.

\section{LIMITATIONS OF THE RESEARCH AND RECOMMENDATIONS FOR FUTURE STUDIES}

For the limitations of this study, the independent variables, moderator variables, and the dependent variables of this research are all done through the employees' assessment; therefore, problems of the homologous variation may occur [52]. Significant correlations among the independent variables, moderator variables, and the dependent variables could be detected because the two share the same source. This is the first limitation of this study. Even so, the main objective of this study is to verify the existence of the moderating effects. And the chances for the moderating effects to be affected by the common method variance (CMV) are relatively low. Therefore, the problem of CMV may be less significant in this study. However, we still suggest the future studies to incorporate the variables of social expectations as control factors or use different sources for data collection when designing a research targeting on this issue.

Furthermore, in the study of human resource management practices and organizational performance, there have been disputes on the issue of whether good human resources management practices result in good organizational performance, or good organizational performance results in good human resources management practices [63]. This study validates the viewpoint that good human resources management practices achieve good organization, but it is also possible that good organization enables good human resource management practices. This poses the second limitation of this research. Although human resource management practices and organizational performance may have reciprocal cause-and-effect relationship, implementation of human resource management practices improves employee attitude. This cause-and-effect relationship is more determined: there should be human resource management practices first, which make the employees feel that the company considers for them before their attitude can be changed. This study collected cross-sectional data, which is less capable of verifying the cause-and-effect 
relationship between human resource management and employee organizational commitment; therefore, we recommended that future studies collect longitudinal data, which will offer more accurately means for verification on the cause-and-effect relationship.

This study used variables at the individual level to measure human resource management practices (organizational level), HR Manager's leadership style (group level), and employee organizational commitment (individual level). In the recent studies on organization, cross-level research methods are advanced research methods. If the cause-and-effect relationship between different levels is analyzed with cross-level methods, the results will be closer to reality. Therefore, using only variables of the individual level to measure variables at the organizational and group levels still poses limitation on this study. Nevertheless, this study emphasizes the importance of perception. In the confrontation with one universal reality, the factor that truly affects employee's attitude and behavioral change is the employees' perception. Therefore, even though this study measured only variables at the individual level, it still has contributions to the study on organization. We suggest that future researches employ cross-level approaches for further study on the related issues.

Another limitation of this study emerges in the relatively low increase volume in the R2 value as shown in Model 3 (0.008). This indicates that after the moderating effect is input into the models, the increase in the interpretative variance is significant. This result foretells that because only two of the six interactive variances are found to have significant effect, two other are found to have partly significant effect, and the rest of the two are found to have no significant effect, $\Delta \mathrm{R} 2$ will be on the low side. And according to [17] on the subject of statistical analysis methods for handling variance interaction, if variables are standardized before multiplication and the results are then subjected under analysis for the interaction of variables, it will under-estimate the presence of the moderating effect. Therefore, although the $\Delta \mathrm{R} 2$ of this study is low, the interactive effect is significant, which indicates that the moderating effect of HR Manager's transformational leadership indeed exists.

This research, studying the moderating effect of HR Manager's transformational leadership, has found that moderating effect does not exist in the effect of education and training and career development on employees' organizational commitment. We suggest that future research may try to find other contingency factors for the effect of human resource management practices on employee organizational commitment. This research studied mainly on the HR Manager's transformational leadership. The transformational leadership of other departmental managers, however, may also affect the employee organizational commitment. Therefore, we recommend that future researches should collect data on the transformational leadership of the department heads for the further exploration of the moderating effect of transformational leadership on the relationship between human resource management practices and employees' organizational commitment.

\section{REFERENCES}

1. Allen, N.J. and Meyer, J.P. 1990. The measurement and antecedents of affective, continuance and normative commitment to the organization. J. Occupation Psychol., 63: 1-18.

2. Allen, N.J. and Meyer, J.P. 1996. Affective, continuance, and normative commitment to the organization: An examination of construct validity. J. Voc. Behav., 49: 252-276. 
3. Angle, H.L. and Lawson, M.B. 1994. Organizational commitment and employees' performance rating: Both type of commitment and type of performance count. Psychol. Report, 75: 1539-1551.

4. Appelbaum, E., Bailey, T., Berg, P. and Kalleberg, A. 2000. A manufacturing advantage: Why highperformance work systems pay off. Ithaca, NY: Comell University Press.

5. Arthur, J. 1994. Effects of human resource systems on manufacturing performance and turnover. Acad. Manage. J., 37: 670-687.

6. Avolio, B.J., Bass, B.M. and Jung, D.I. 1995. Multifactor leadership questionnaire technical report. Redwood City, CA: Mind Garden.

7. Bartlett, K. 2001. The relationship between training and organizational commitment: A study in the health care field. Hum. Resour. Dev. Q., 12: 335-352.

8. Bass, B. 1985. Leadership and performance beyond expectations. New York: Free Press.

9. Becker, B. and Huselid, M. 1998. High performance work system and firm performance: A synthesis of research and managerial implications. Res. Person. Hum. Resourc. Manage., 16: 53-101.

10. Becker, B.E., Huselid, M.A., Pickus, P.S. and Spratt, M.F. 1997. HR as a source of shareholder value: Research and recommendations. Hum. Resour. Manage. J., 36: 39-47.

11. Browning, V. 2006. The relationship between and HRM practices and service behaviour in South African service organizations. Intl. J. Hum. Resour. Manage., 17: 1321-1338.

12. Burns, J. 1978. Leadership. New York: Harper and Row.

13. Chan, L.M., Shaffer, M.A. and Snape, E. 2004. In search of sustained competitive advantage: The impact of organizational culture, competitive strategy, and human resource management practices on firm performance. Intl. J. Hum. Resour. Manage., 15: 17-35

14. Chang, E. 2005. Employee's perception of HRM effectiveness. Hum. Relat., 58: 523-543.

15. Chang, H.T., Liou, J.W., Miao, M.C. and Tung, C.L. 2011. The relationships between supervisor's mood contagion and employee's innovative behavior: The mediating roles of work engagement and burnout. J. Hum. Resour. Manage., 11: 1-24.

16. Change, E. 1999. Career commitment as a complex moderator of organizational commitment and turnover intention. Hum. Relation, 52: 1257-1278.

17. Cohen, J., Cohen, P., West, S.G. and Aiken, L.S. 2003. Applied multiple regression/correlation analysis for the behavioral sciences ( $3^{\text {rd }}$ ed.). Mahwah, NJ: Erlbaum.

18. Conway, E. 2004. Relating career stage to attitudes towards HR practices and commitment: Evidence of interaction effects? European J. Word Occupational Psychol., 13: 417-446.

19. Delery, J. and Doty, D. 1996. Modes of theorizing in strategic human resource management: Tests of universalistic, contingency, and configurational performance Predictions. Acad. Manage. J., 39: 802-835.

20. Delaney, J. and Huselid, M. 1996. The impact of human resource management practices on perceptions of organizational performance. Acad. Manage. J., 39: 949-969. 
21. Federico, V. 1996. Relationship between communication satisfaction and organizational commitment in three Guatemalan organizations. J. Bus. Commun., 33: 111-140.

22. Fletcher, C. and Williams, R. 1996. Performance management, job satisfaction, and organizational commitment. Br. J. Manage., 7: 169-179.

23. Gartner, K. and Nollen, S. 1989. Career experience, perceptions of employment practices and psychological commitment to the organization. Hum. Relat., 42: 975-991.

24. Gould-Williams, J. 2003. The importance of HR practices and workplace trust in achieving superior performance: A study of public-sector organization. Int. J. Hum. Resour. Manage., 14: 28-51.

25. Gould-Williams, W.J. and Davies, F. 2005. Using social exchange theory to predict the effects of HRM practice on employee outcome. Public Manage. Rev., 7: 1-24.

26. Guest, D. 1997. Human resource management and performance: A review and research. Intl. J. Hum. Resour. Manage., 8: 263-276.

27. Guest, D.E., Michie, J.N. and Sheehan, M. 2003. Human resource management and corporate performance in UK. Br. J. Ind. Relat., 41: 291-314.

28. Hackett, R., Bycio, P. and Hausdorf, P. 1994. Further assessments of Meyer and Allen's three-component model of organizational commitment. J. Appl. Psychol., 79: 15-23.

29. Heshizer, B. 1994. The Impact of flexible benefits plans. Benefits Quart., 10: 84-90.

30. Chang, H.H. 2011. Study of stressors, organizational identification, and job performance of room division department employees in the international tourist hotels: Coping behavior as a moderater. J. Hum. Resour. Manage., 11: 1-25.

31. Hsu, S.W. and Chang, H.H. 2010. Study of trans formational leadership, service climate and serviceoriented citizenship behavior of cabin attendants in the international airline: Locus of control personality traits as a moderator. J. Hum. Resour. Manage., 10: 53-77.

32. Huselid, M. 1995. The impact of human resource management practices on turnover, productivity, and corporate financial performance. Acad. Manage. J., 38: 635-672.

33. Jaramillo, F., Mulki, J.P. and Marshall, G.W. 2005. A meta-analysis of the relationship between organizational commitment and salesperson job performance: 25 years of research. J. Bus. Res., 58: 705-714.

34. Jones, G. and Wright, P. 1992. An economic approach to conceptualizing the utility of human resource management practices. Res. Person. and um. Resour. Manage., 10: 271-299.

35. Judge, Y. and Piccolo, R. 2004. Transformational and transactional leadership: A meta-analytic test of their relative validity. J. Appl. Psychol., 89: 755-768.

36. Karami, A., Analoui, F. and Cusworth, J. 2004. Strategic human resource management and resource-based approach: The evidence from British manufacturing industry. Manage. Res. News, 27: 50-68. 
37. Lai, Y.R. and Huang, T.C. 2007. The moderating effect of the Perecived transformational leadership on the relationship of human resource management practices and affective commitment. J. Hum. Resour. Manage. Rev., 7: 93-111.

38. Lin, J.S.J. and Lin, S.C. 2011. Moderating effect of organizational climate on the relationship of organizational support and service-oriented organizational citizenship behaviors. Afr. J. Bus. Manage., 5: 582-595.

39. Lin, J.S.J., Lin, S.C. and Lin, B.Y. 2010. The moderating effects of employee personality characteristics on organizational commitment during periods of organizational change. Afr. J. Bus. Manage., 4: 3681-3690.

40. Lin, J.S.J., Lin, S.C. and Lin, Y.F. 2011. The moderating effects of the organizational socialization on leader-member relationship and job stress. Afr. J. Bus. Manage., 5: 10144-10155.

41. Lin, S.C. and Lin, J.S.J. 2011. Impacts of coworkers' relationships on organizational commitment and intervening effects of job satisfaction. Afr. J. Bus. Manage., 5: 3396-3409.

42. Ling, Y.H. and Hung, L. 2010. The influence of intellectual capital on organizational performance: The mediation effect of intellectual capital management strategy. J. Hum. Resour. Manage., 10: 1-27.

43. Macduffie, J. 1995. Human resource bundles and manufacturing performance: Organizational logic and flexible production systems in the world auto industry. Ind. Labor Relat. Rev., 48: 197-221.

44. Mathieu, J.E. and Zajac, D.M. 1990. A review and meta-analysis of the antecedents, correlates, and consequences of organizational commitment. Psychol. Bull., 108: 171-194.

45. Meyer, J.P., Paunonen, S.V., Gellatly, I.R., Goffin, R.D. and Jackson, D.N. 1989. Organization commitment and job performance: It's the nature of the commitment that counts. J. Appl. Psychol., 74: 152-156.

46. Mowday, R., Porter, L. and Steer, R. 1982. Employee-organizational linkage: The psychology of commitment, absenteeism, and turnover. New York: Academic Press.

47. Neal, A., West, M.A. and Patterson, M.G. 2005. Do organizational climate and competitive strategy moderate the relationship between human resource management and productivity? J. Manage., 31: 492-512.

48. Ngo, H. and Tsang, A. 1998. Employment practices and organizational commitment: Differential effects for men and women? Intl. J. Org. Anal., 6: 251-266.

49. Ogilvie, J.R. 1986. The role of human resource management practices in predicting organizational commitment. Group Org. Stud., 11: 335-359.

50. Paul, A.K. and Anantharaman, R.N. 2003. Impact of people management practices on organizational performance: Analysis of a causal model. Intl. J. Hum. Resour. Manage., 14: 1246-1266.

51. Pfeffer, J. 1998. The human equation. Cambridge, MA: Harvard Business School Press.

52. Podsakoff, P. and Organ, D. 1986. Self-reports in organizational research: Problems and prospects. $J$. Manage., 12: 531-544. 
53. Putti, J.M., Aryee, S. and Phua, J. 1990. Communication relationship satisfaction and organizational commitment. Group Org. Stud., 15: 44-52.

54. Robbins, S.P. 2005. Organizational behavior ( $7^{\text {th }}$ ed.). NJ: Peatson Hall.

55. Snell, S. and Dean, J. 1992. Integrated manufacturing and human resource management: A human capital perspective. Acad. of Management J., 35: 467-504.

56. Somers, M.J. and Birnbaum, D. 1998. Work-related commitment and job performance: It is also the nature of the performance that counts. J. Org. Behav., 19: 621-635.

57. Sturman, M. 2000. Implications of utility analysis adjustment for estimates of human resource intervention value. J. Manage., 26: 281-299.

58. Suliman, A. and Iles, P. 2000. Is continuance commitment beneficial to organizations? Commitmentperformance relationship: A new look. J. Manage. Psychol., 15: 407-422.

59. Thorsteinson, T.J. 2003. Job attitudes of part-time workers: A meta-analytic review. J. Occupation Org. Psychol., 76: 151-177.

60. Weathington, B.L. and Tetrick, L.E. 2000. Compensation or right: An analysis of employee "fright" benefit perception. Employee Responsibilities Right J., 12: 141-162.

61. Williams, M.L. and MacDermid, S.M. 1994. Linkage between employee benefits and attitude and behavioral outcomes: A research review and agenda. Hum. Resour. Manage. Rev., 4: 131-160.

62. Wright, P.M., Gardner, T.M. and Moynihan, L.M. 2003. The impact of HR practices on the performance of business units. Hum. Resour. Manage. J., 13: 21-36.

63. Wright, P.M., Gardner, T.M., Moynihan, L.M. and Allen, M.R. 2005. The relationship between HR practices and firm performance: Examining causal order. Person. Psychol., 58: 409-446.

64. Wu, C.C., Liao, S.H., Hu, D.C. and Lo, W.P. 2011. The Relationships among organizational commitment, knowledge sharing, and organizational citizenship behavior: A case of Taiwan semiconductor industry. J. Hum. Resour. Manage., 11: 77-101.

65. Youndt, M.A., Snell, S.A. Jr., Dean, J.W. and Lepak, D.P. 1996. Human resource management, manufacturing strategy, and firm performance. Acad. Manage. J., 39: 836-866. 
